\title{
The Influence of Consumerism Culture on the Ideology of College Students Under the Background of "Internet +" Impact and Response Research
}

\author{
Ruirui Chen ${ }^{1} \&$ Chuansha Bo ${ }^{1}$ \\ ${ }^{1}$ Shandong Jiaotong University, Jinan, China \\ Correspondence: Ruirui Chen, Shandong Jiaotong University, No. 5001, Haitang Road, Science and Technology \\ Park, Changqing University, Jinan, Shandong, China. E-mail: 893934523@qq.com
}

Received: December 2, 2021

Accepted: December 20, $2021 \quad$ Online Published: December 23, 2021

doi:10.20849/ajsss.v6i5.968

URL: https://doi.org/10.20849/ajsss.v6i5.968

\begin{abstract}
As a value concept of Western capitalism, consumerism culture is the manifestation and new carrier of Western ideology in contemporary society. With the development of globalization, the characteristics of extreme individualism, hedonism, and commodity fetishism of consumerism culture have biased guidance and negative influence on the mainstream ideology of college students. As the main front of talent training, universities must adhere to the guiding position of Marxism in the field of ideology, avoid the multiple hidden penetration and diffuse transmission of consumerist ideology, and make full use of the communication advantages of "Internet +" to strengthen the mainstream ideology The guiding role of the students is to guide students to strengthen the "four self-confidence", form an internal ideological and cultural consciousness, and build a reasonable and scientific consumer culture atmosphere.
\end{abstract}

Keywords: consumerism culture, ideology, "Internet +", college students

Since the 18th National Congress of the Communist Party of China, General Secretary Xi Jinping has made a series of important discussions on ideological work from a strategic and overall perspective. He pointed out that to do well in ideological work in the new era, we must uphold and strengthen the party's overall leadership of ideological work, firmly grasp the leadership of ideological work, better consolidate and develop mainstream ideology, and continuously strengthen ideology. Domain dominance and discourse power, constantly strengthen the road, theoretical, institutional, and cultural confidence of the broad masses of cadres and the masses, and continuously enhance the cohesion and centripetal force of the party, the country, and the nation. 1 As the frontier of ideological work, colleges and universities shoulder the fundamental task of cultivating socialist qualified builders and reliable successors. As a form of ideology, consumerism culture has emerged with the Western consumer society. With the help of mass media, especially with the help of "Internet +", the content is advocating and pursuing excessive material possession or symbolic consumption. , For the purpose of ensuring and maintaining capital accumulation and its relationship of interest. 2 At present, as Western consumerism is spreading and infiltrating our country through various methods through globalization, doing a good job in ideological education for college students is both the top priority and the most urgent task.

\section{The Cultural Representation of College Students' Consumerism}

Our country research on consumer society, consumer culture, and consumerism is still in its infancy. "Consumer Culture Theoretical Research-Based on the Perspective of Globalization and the Dimension of History" defines consumerism as: "Consumerism is a modern capitalism from the" A new form and stage of consumption culture formed by the transition from a production-oriented society to a consumption-oriented society. It is a unique way of life, that is, the purpose of consumption is not to satisfy actual needs, but to be manufactured by continuous pursuit. The satisfaction of the stimulated desire." 3 scholar Huang Ping believes: "Consumerism, as a value concept and lifestyle, is essentially not in 'need' but in the constant pursuit of 'desire' that is difficult to fully satisfy (Desire) What it represents is people's incited consumer passion and stimulated consumer desire." 4 College students are active and open, with unimpeded internet channels, and they are extremely vulnerable to the harmful erosion of consumerist culture, which affects their personal outlook on the world, outlook on life, etc. Values even affect the collective identity of the mainstream socialist ideology. 


\subsection{Sign-Led Consumption Tendency}

The famous French sociologist Jean Baudrillard regards the theory of symbolic consumption as the core concept of consumer culture. In the context of consumerism culture, producers symbolize commodities. In fact, commodities given symbolic meaning are separated from the use value and labor value of the commodity itself. Roland Barthes said in his "Semiotic Principles": "In order to inactivate the buyer's sense of calculation, things must be covered with a veil-an image, rational, and meaningful veil, creating a kind of The virtual image makes it the direction of consumption... Radical desire is not a thing, but a name, not a dream, but a meaning." 5 The "meaning" referred to here is an ideology with a certain tendency. In modern society, the Internet has become an indispensable medium for people to keep in touch with people, people and things, and people and the world. It has also become a fast lane for consumerism to further diffuse into the micro-life of the masses. For example, the current more popular live streaming products, the consumption mode led by Li Jiaqi and Wei Ya live room sales has become the favorite of young people, creating a sense of ritual and satisfaction of consumer behavior. Lipsticks endowed with various symbolic meanings, various brand outfits, beauty accessories, etc. have become status symbols for many women in shaping their self-image. College students, especially female groups, are inevitably trapped in this type of consumption vortex.

\subsection{Consumer Content Centered on Entertainment}

The popularity of consumerism culture is because the consumer society environment continuously creates consumer desires and continuously encourages consumer groups' impulse to consume. IiMedia Data Center's analysis of the average monthly consumption amount of leisure and entertainment of Chinese college students in 2021 shows that $41.5 \%$ of college students have an average monthly leisure and entertainment consumption of less than 500 yuan; $35 \%$ of college students whose average monthly consumption is $500-1,000$ yuan ; $17.5 \%$ of college students have an average monthly consumption of 1001-2,000 yuan; the average monthly consumption of 2,000 yuan is the least of college students, only 6\%. 6 Through the author's actual investigation and research, it is found that college students generally invest more energy and financial resources in live broadcasting, short videos, and games. In the case of better and better family conditions, the living expenses of some students have been rising year by year, which provides the primary basis for entertainment consumption. For example, some boys buy higher prices and higher prices in order to chase the excitement and sense of accomplishment brought by games. In order to enhance the virtual game experience, more and more students purchase virtual equipment through game recharge; more consumption of girls is to purchase cosmetics and image wear through live broadcast; in addition. The amount of money that college students spend on dating is not a few. With the help of electronic devices such as mobile phones and computers, consumerist-made entertainment content has continuously strengthened college students' pursuit of pan-entertainment. The more pan-entertainment content, the larger the scale of college students' consumerism.

\subsection{Means of Consumption in the Form of Media}

The media takes the guidance and stimulation of consumption as the entry point, and uses seductive and inflammatory communication to continuously create virtual worlds on the basis of the real environment, gradually blurring and dissolving the boundary between the "public sphere" and the "private sphere" , Making the "separated society" and the "silent majority" more obvious, so that the public becomes the one-dimensional person described by Marcuse, and gradually loses the ability to communicate with the world and the ability to think independently. In the era when the masses are inseparable from mass media, the media is information that validates McLuhan's point of view, and because of this, consumerist culture uses mass media as a communication tool to guide and control consumption trends. In the survey, in addition to the essential applications of the mobile phone software of college students, most of the entertainment software, such as Douyin, Xiaohongshu, Tencent Video, Toutiao, Wangyiyun Music, Kuaishou, Bilibili, Watermelon Video, With the help of these social and entertaining software, students have changed the way of connecting with the outside world, realizing self-identification and self-expression in the virtual, and at the same time, the abstract rational thinking of the perception model is constantly disappearing from the stimulation of the concrete sensuality. Has gradually become a loyal supporter of consumerist culture. Consumerism shapes consumption as a systematic behavior of manipulating symbols, and uses mass media to create consumption sentiments of "what I consume, what I am" and "decay if I don't consume", and gradually grasp the right to speak and dominate to influence Consumer ideology.

\section{The Influence of Consumerism Culture on the Mainstream Ideology of College Students}

\subsection{The Alienation of Consumer Behavior Intensifies the Alienation of the Essence of the Subject}

The commodity fetishism of consumerist cultural ideology leads to the alienation of the consumer behavior of 
the consumer subject, which in turn leads to the alienation of the subject itself. Commodity fetishism was first proposed by Marx in his "Das Kapital", that is, "Commodity forms reflect the social nature of people's own labor into the nature of labor products themselves, and reflect the natural social attributes of these things in front of people. Therefore, the social relationship between the producer and labor is reflected as the relationship between things and things that exist outside the producer. Due to this conversion, the product of labor becomes a commodity, a sensible and super-sensible thing or society. The thing." 7 When the public worships commodities, and the increasing will directly lead to the materialization of people, which results in the result that people are dominated by things. Materialization is a kind of alienation that Marx refers to. Consumerism culture is the mass media that can produce consumer cultural products in large quantities, and even cultural products with a certain ideological penetration. The essence of "selling" products is to create the illusion of freedom and happiness, such as brushing one after another. Audio and short video, I watched a funny joke, stayed up all night to watch the live broadcast, and spent a whole day for game after game... When college students are submerged in fashionable consumer behavior and superficial When the aesthetic taste and critical consciousness and ability are gradually weakened, which conceals the severely materialized subject-object contradiction, the group of college students as independent individuals is deeply caught in the trap of consumerism culture, and eventually becomes the slave of the commodity, which is also the thing. Or accessories, exacerbating the alienation of college students. This kind of alienation is precisely criticized by Marxism. It advocates that people should have subject consciousness and that people are the masters of things. However, in an environment that is increasingly surrounded by consumerism culture, college students are increasingly being dominated by various commodities. Captives work in the opposite direction to the training goals of socialist builders and successors.

\subsection{Consumerism Contributes to the Extravagance of Campus Enjoyment}

Following hedonism is also a level emphasized and guided by consumerism, and this hedonism and luxury is directly manifested in excessive pursuit of material life and extremely impulsive consumption behavior. In a society filled with a grand consumer culture landscape, you can see long queues waiting to buy Internet celebrity food in the bustling market, and you can also see the crowds of Internet celebrities punching in; there are also big promotions and doubles in 618 every year. Eleven double twelve shopping spree. According to the author's survey, contemporary college students are extremely keen on things with the prefix "net celebrity", the value of online shopping cart products far exceeds the monthly living expenses, and a small number of students are keen to show their status with luxury goods and famous brand products. These appearances are all Focus on irrational consumption. The current irrational consumption characteristics are as follows: On the one hand, consumption is not based on actual needs, but more on impulse; on the other hand, the meaning of consumption may not lie in the consumption of use value, nor the use of symbols. The appropriation of value only lies in the moment of payment, consumption no longer needs any reason, just consumption. 8 And with the help of conspicuous consumption, some college students use "Huabe" and "Jingdong Baitiao" methods to fill up the gaps in their inner consumption desires, and some students even embarked on the road of no return to campus loans. Irrational consumption patterns have seriously affected the good atmosphere of college campuses, and even run counter to the core socialist values.

\subsection{Consumerism Dispels Students and Cultivates Three Correct Outlooks}

Because consumerism culture creates an illusion of carnival, the "freedom of consumption" and "equality of consumption" it advocates are an illusory social ideology, but it guides and entices the general public, especially the pursuit of the unreasonable pursuit of college students. Whether in the West or China, the extreme preference of consumerist culture for "freedom" and "equality" will not work. General Secretary Xi Jinping once emphasized that "the adolescent stage is the'joint booting stage' of life, and it is most in need of careful guidance and cultivation." For young students who are in the critical period of their growth, the development of outlook on life, world outlook, and values is very important. During the university period, the three views of students have not matured, especially the choice of values is more contemporary and autonomous. While the mass media enriches university life and plays an active role, it also conveys the ideology of consumerist culture and hides reverse guidance. In a symbolic consumption atmosphere concocted by consumerism, college students are constantly being stimulated in their consumption desires in terms of study consumption, game consumption, entertainment consumption, food consumption, clothing consumption, etc. When they cannot make correct value judgments and choices, The pan-entertainment and non-depth consumption content created by consumerism culture satisfies the psychological needs of college students to be full of curiosity, desire to enjoy, display status, and strengthen ostentation. In this meaningless self-expression, they lose the independent thinking and values that the subject should have., The mainstream ideology has been severely corroded. 


\section{Decompose the Countermeasures Against the Influence of Consumerism on the Mainstream Ideology of College Students}

In order to become a strong position for implementing the fundamental task of establishing morality, colleges and universities must adhere to the guiding position of Marxism in the field of ideology, firmly grasp the "discourse power" and "initiative power" of mainstream ideology, and reduce or avoid consumerist cultural influence. Infiltrate the ideals and beliefs of college students, actively cultivate and practice socialist core values, strengthen college students' identification with mainstream ideology, and build a position of socialist ideology in colleges and universities.

\subsection{Using the Internet as a Medium to Strengthen the Positive Guidance and Active Identification of Mainstream Ideologies}

The mass media is a double-edged sword. The positive guidance of mainstream ideology is strengthened in the context of Internet+. Colleges and universities must insist on reverse criticism, pay attention to positive voices, and use various online media to strengthen ideological education, ideological and political education. General Secretary Xi Jinping said When presiding over the twelfth collective study of the Political Bureau of the Central Committee, he emphasized: "Create a new type of communication platform, build a new type of mainstream media, expand the territory of mainstream value influence, and let the party's voice spread more widely, more widely, and more deeply. "9 Colleges and universities should actively expand communication platforms, seize communication positions, establish special Marxist theory websites and WeChat platform columns, make good use of campus broadcasts, provide abundant network ideological learning resources, and actively cultivate a group of people who are consistent with mainstream ideology. "Opinion leaders" guide the trend of public opinion, carry out good ideological education and online ideological and political education with a clear-cut stand and quiet, cultivate students to develop the correct three views and establish firm beliefs. At the same time, further strengthen the management and supervision of the media of colleges and universities, resolutely resist the bad views and behaviors of consumerism culture, purify the cyberspace, encourage college students to create positive online cultural works, spread positive energy, and create a positive and healthy online environment for college students. Continuously improve college students' sense of identity with mainstream ideology.

\subsection{Student-Oriented, Constructing a Cultural Front in Colleges and Universities Led by the Mainstream Socialist Ideology}

Culture is the carrier and form of ideology. Colleges and universities are the main front for exchanging ideas, inheriting civilization, and cultivating talents. College students, as the main body of education, must always adhere to cultural self-confidence. Basic, deeper, and more lasting cultural self-confidence force, integrated into the whole process of college ideological and political education and humanities and social sciences teaching, guide college students to form an internal cultural consciousness; establish the dominant position of mainstream ideology in college teaching, and build socialism The cultural position dominated by the mainstream ideology strengthens college students' identification with the mainstream ideology. Adhere to student-oriented, care for students, patiently listen to students, carry out mainstream cultural propaganda and education based on the actual situation of students, actively promote students to participate in social practice, let students actively abandon bad behaviors in experience, and strengthen the effectiveness of education. Under the Internet + perspective, we must further expand the influence of the "four self-confidence", enhance the confidence of the mainstream socialist ideology, and increase the charm of the mainstream socialist ideology in the Internet. The mainstream ideology must be bold in "bright sword" and good at "bright sword" "To secure the cultural position of colleges and universities dominated by the mainstream socialist ideology. Western consumerism culture as a new ideological carrier, its hidden and rapid development and dissemination in our country have had a great impact on the mainstream ideological identity of college students, which should not be underestimated. Therefore, colleges and universities must strengthen ideological and political education and ideological education, establish resistance to the adverse effects of consumerist culture on college students, adhere to the guiding position of Marxism in the field of ideology, and build a more solid and solid steel Great Wall of mainstream ideology .

\section{References}

Barthes, R. (1988). Principles of Semiotics, translated by Li Youzheng. Beijing: Life-Reading.Xinzhi Sanlian Bookstore.

From the Central Broadcasting Network. Bigger and stronger mainstream public opinion-General Secretary Xi Jinping's important speech during the twelfth collective study of the Political Bureau of the CPC Central $\begin{array}{lcc}\text { Committee } & \text { led. } & \text { Retrieved } \\ \text { https://baijiahao.baidu.com/s?id=1623774704706566634\&wfr=spider\&for=pc }\end{array}$ 
Huang, P. (1997). Unfinished narration. Sichuan People's Publishing House.

iMedia.com. Retrieved from https://www.iimedia.cn/c1061/77717.html

Ji, Z.-P. (2010). Consumerism culture-a form of ideological existence. Tianfu New Theory, (2), 115-119.

Li, J. (2018). The influence of western consumerism culture on college students' mainstream ideology and its response. Journal of Anhui University of Science and Technology (Social Science Edition), 20(6), 92-96.

Tan, S. (2021). Research on the influence of consumerism culture on the mainstream ideology of college students. Journal of Taiyuan Urban Vocational and Technical College, (4), 134-136.

$\mathrm{Xu}, \mathrm{W}$. (2015). Interpretation of Consumer Society, Consumer Culture and Cultural Consumer Theory --- Study on the Social Environment of Cultural Industry. Art Hundreds of Arts, 31(S1), 23-29.

Yang, K., \& Dong, Y.-L. (2003). Consumer culture: from modern to post-modern. Beijing: China Social Sciences Press, p. 130.

Yang, K., \& Dong, Y.-L. (2013). Theoretical Research on Consumer Culture: Based on the Perspective of Globalization and the Dimension of History. People's Publishing House, p. 127.

Zheng, J. (2019). Firmly grasp the initiative of online ideological work. Red Flag Manuscript, (3), 29-31+1.

\section{Copyrights}

Copyright for this article is retained by the author(s), with first publication rights granted to the journal.

This is an open-access article distributed under the terms and conditions of the Creative Commons Attribution license (http://creativecommons.org/licenses/by/4.0/). 